\title{
Chinese Education Movement in Malaysia: A Study about Dong Jiao Zong Struggle (1970-2002) (Malay Version)
}

\author{
Iqbal U* and Ali Seman A
}

History Programme, Faculty of Social Sciences and Humanities, National University of Malaysia, Malaysia

*Corresponding author: Iqbal U, History Programme, Faculty of Social Sciences and Humanities, National University of Malaysia, UKM 43650, Bangi Selangor, Malaysia, Tel: 60389215555; E-mail: uqbah@siswa.ukm.edu.my

Received date: June 16, 2016; Accepted date: June 17, 2016; Published date: June 20, 2016

Copyright: ( 2016 Iqbal U, et al. This is an open-access article distributed under the terms of the Creative Commons Attribution License, which permits unrestricted use, distribution, and reproduction in any medium, provided the original author and source are credited.

Citation: Iqbal U, Ali Seman A (2016) Chinese Education Movement in Malaysia: A Study about Dong Jiao Zong Struggle (1970-2002) (Malay Version). Arts Social Sci J 7: 198. doi:10.4172/2151-6200.1000198

\section{Opinion}

Written by Cheong Yuen Keong, this book was originally the author's doctoral thesis entitled "Chinese Education Movement in Malaysia: A Study about Dong Jiao Zong Struggle (1970-2002)" submitted to the Faculty of Arts and Social Sciences, University of Malaya in December 2007. The study reviewed the Chinese Education Movement in Malaysia that is more focused on Dong Jiao Zong fight between the periods 1970 to 2002. As a multi-ethnic society of the country, the government seeks to foster national integration and nation building through education channels. National Education Policy which is designed hopes to use the national language as the main medium of instruction in all schools in order to create a single stream school system that can foster national integration. The implementation of the National Education Policy was perceived as an act to erode the rights of education, language and culture of minority communities by certain groups in Chinese society. Thus has triggered the Chinese education movement lead by Dong Jiao Zong to defend the continuation of Chinese education in Malaysia.

Chinese education movement exists due to the implementation of the National Education Policy that supports the ultimate objective of the Razak Report which leads to the formation of a single stream education system using the national language as the language of instruction. Excitement government to produce that goal has been perceived as an action to block the development of Chinese education and school identity erodes China by Dong Jiao Zong. Chinese Education Movement arcing problems observed by a framework of ethnic conflicts between nation-state formation and retention of ethnic identity, disputes the perception of pluralistic concept in the field of education and language as the fertilization of the school system with multi-stream flow. So, the dilemmas of Chinese education are a fundamental problem in this book.

Dong Jiao Zong struggle to deal with the various dilemmas that became the core of the research in this book. Dong Jiao Zong struggle is viewed from the struggle which sparked the interest of sustainable social movements and influential. Dong Jiao Zong effectiveness of the fight in terms of the effectiveness of the struggle for a nongovernmental organization on the goal to achieve. Also examined the impact of the struggle on various aspects, in terms of education, political and social development in Malaysia.
The study found that the objectives of the Dong Jiao Zong has not changed, that defend or fight for the Chinese education system complete and recognized by the government, but for the sake of realizing its achievements, Dong Jiao Zong adopt a different fight a different intervals on the implementation of government policies and development political current. In the 1950s, the approach of consultation with the political parties held that Chinese schools are recognized in the national education system, while in the late 1960s also achieve energy and community support that for the establishment of Universiti Merdeka allowed, by the 1970s also focused on struggle to rebuild and gain the confidence of the Chinese people against the Chinese private secondary schools. In the 1980s Dong Jiao Zong had tried various strategies including the political parties in general elections in 1982 and 1990. By the 1990s, claims that the shortage of Chinese primary schools in urban areas and the construction of Private Higher Education Institutions also become the theme of struggle important. The scope of the struggle has shifted from the struggle to defend the rights of Chinese education to the struggle to defend the rights of mother-tongue education for all ethnic groups since the mid-1980s. And cooperation with non-governmental organizations of various races begins to prevail so that the struggle was not viewed as a narrow racial struggle.

The study also found that the fight Dong Jiao Zong impact and influence on Chinese society and the state. Dong Jiao Zong's ability to influence the voting pattern of Chinese society led to the political parties to take serious note of establishment and the government also provides a compromise to the development of Chinese schools. Now there is 1286 pieces of Chinese national type schools in the national education system, with 60 independent Chinese secondary schools using the school system, curriculum and examination are conducted by Dong Jiao Zong and 3 Private Higher Education Institutions in China, is one of the crucial struggles of Dong Jiao Zong. Dong Jiao Zong is a non-governmental organization that has contributed in the development of education in Malaysia. The book is divided into eleven chapters. It is one of the most extensive efforts in the field of Chinese education movement from the decade of independence to the 2000 s. 